\title{
Effects of Soft X-Ray Irradiation on NK Cell Activity and the Percentage of Asialo GM1-Positive Cells in Spleen Cells of Mice
}

\author{
Minoru TAKEUCHI and Hiroshi SHIBATA ${ }^{1)}$ \\ Department of Biotechnology, Faculty of Engineering, Kyoto Sangyo University, Kamigamo Motoyama, Kita-ku, Kyoto 603 and \\ ${ }^{1)}$ Department of Veterinary Pharmacology, Faculty of Agriculture, Yamaguchi University, Yoshida, Yamaguchi 753, Japan \\ (Received 1 October 1996/Accepted 7 January 1997)
}

ABSTRACT. Effects of soft X-ray irradiation on the natural killer (NK) cell activity and the percentage of asialo GM1-positive cells of spleen cells in mice were investigated by using a soft X-ray generator intended for non-destructive radiological examination. Soft X-ray irradiation in graded doses of more than $25.8 \mathrm{mC} / \mathrm{kg}$ indicated dose dependent reductions in the NK cell activity in the spleen of irradiated mice. Significant reductions in the population of asialo GM1-positive cells in spleen cells were also observed. These results suggest that a soft X-ray generator could also be useful in immuno-irradiation studies. — KEY wORDS: asialo GM1-positive cell, NK cell activity, soft $\mathrm{X}$-ray.

J. Vet. Med. Sci. 59(5): 413-414, 1997

Various immune disfunctions induced by hard X-ray irradiation have been widely reported in numerous clinical and experimental investigations [6, 7]. It has been shown that hard X-ray irradiation has a destructive action on immune system cells and organs, and depresses their functional activity. Recently, in the non-destructive examination of light metals and chemical products, and in the teratology study of experimental animals, soft X-rays have been widely used [5]. We previously reported that soft X-ray irradiation decreased lymphocyte, neutrophil and total leukocyte counts, plaque forming cell counts, delayed type hypersensitivity reaction, mitogenic activity, and inhibited the tumor growth in mice [11-14]. However, the effects of soft X-ray irradiation, generated from apparatus intended for non-destructive examination, on immunological studies of animals have been less well characterized. In this study, we studied the effect of soft X-ray irradiation on the function of the natural killer (NK) cell which is important to the immune system for host defense as well as immunological functions, and the feasibility of applying soft $\mathrm{X}$-rays to radiation cell immunological studies by using a soft X-ray generator intended for non-destructive radiological examination.

Female C57BL/6 mice at 10 weeks of age were used in this experiment. Five mice were subjected to each expose dose in each experiment. Irradiation with soft X-rays was performed by using an apparatus generating soft X-rays, SOFRON NST-1005C. The irradiation conditions were the same as those in a previous work [11]: $50 \mathrm{~cm}$ distance (focus-skin distance), $70 \mathrm{kVp}, 5 \mathrm{~mA}$. Exposure doses were $25.8,77.4,154.8$ and $258 \mathrm{mC} / \mathrm{kg}$, determined on the surface skin of the mouse with Victoreen 666. The dose rate used was $17.2 \mathrm{mC} / \mathrm{kg} / \mathrm{min}$ for irradiation, and the half-value layer was $0.15 \mathrm{~mm} \mathrm{Al}$. In this study, we used the irradiation dose, because the absorbed dose of soft X-ray irradiation could not be determined in the spleen. The spleens of irradiated mice were obtained at 1 day after irradiation. The spleen was cut into small pieces with scissors and then pressed through a 100-mesh stainless steel sieve with RPMI 1640 medium. Erythrocytes were lysed by osmotic shock for 10 seconds. The nucleated spleen cells were suspended in RPMI 1640 medium with $10 \%$ FCS at a concentration of $1 \times 10^{7}$ cells $/ \mathrm{ml}$. The spleen cell suspension was placed in plastic dishes and incubated at $37^{\circ} \mathrm{C}$ for $1 \mathrm{hr}$. After $1 \mathrm{hr}$, nonadherent spleen lymphocytes were collected and suspended in RPMI 1640 medium with $10 \%$ FCS at a concentration of $1 \times 10^{7}$ cells $/ \mathrm{m} l$. The YAC- 1 lymphoma derived from A-Sn mice were used as target cells for the assay of the NK cells activity [1]. $5 \times 10^{6}$ cells were labeled by addition of $100 \mu \mathrm{Ci} \mathrm{Na}{ }^{51} \mathrm{CrO}_{4}$ and incubated for $1 \mathrm{hr}$ at $37^{\circ} \mathrm{C}$ with occasional shaking.

The NK cell activity was measured as described previously [9]. Briefly, nonadherent spleen lymphocytes as effector cells and labeled target cells were added at effector to target $(\mathrm{E} / \mathrm{T})$ ratio of $100: 1$ to plates. The plates were then centrifuged and incubated at $37^{\circ} \mathrm{C}$ for $6 \mathrm{hr}$. Then supernatants from triplicate wells were counted in a gamma counter as NK cell activity. Analysis of asialo GM1-positive cells was performed by flow cytometory. Nonadherent spleen lymphocytes were suspended at a concentration of 1 $\times 10^{7}$ cells $/ \mathrm{m} l$ in RPMI 1640 with $10 \%$ FCS. The monoclonal antibody used anti-asialo GM1 antibody as a marker for the NK cell [4]. The dilution rate of the antibody was 100 -fold. The cell suspension was placed in plastic tubes, and anti-asialo GM1 antibody was added. After mixing, the mixture was incubated for $60 \mathrm{~min}$ at $4{ }^{\circ} \mathrm{C}$. The cells were washed twice in PBS with $1 \%$ FCS and $0.1 \%$ sodium azide. The second antibody, fluorescein isothiocyanate (FITC)-labeled goat anti-mouse IgG antibody was diluted 20 -fold and was added to the mixture and reaction was performed at $4^{\circ} \mathrm{C}$ for $30 \mathrm{~min}$. After washing, the cell suspension was analyzed by FACS.

Mice were given whole body irradiation of doses from 25.8 to $258 \mathrm{mC} / \mathrm{kg}$ of soft X-rays. NK cell activity and the percentage of asialo GM1-positive cells were measured at 1 day after irradiation. NK cell activity was significantly suppressed by irradiating with $25.8 \mathrm{mC} / \mathrm{kg}$ of soft X-rays $(11.8 \pm 1.3 \%$, mean \pm S.E., $\mathrm{p}<0.05), 77.4 \mathrm{mC} / \mathrm{kg}$ irradiation $(4.4 \pm 0.9 \%, \mathrm{p}<0.01), 154.8 \mathrm{mC} / \mathrm{kg}$ irradiation $(2.2 \pm 0.5 \%$, $\mathrm{p}<0.01), 258 \mathrm{mC} / \mathrm{kg}$ irradiation $(1.4 \pm 0.5 \%, \mathrm{p}<0.01)$ when compared with the non-irradiated control group (16.3 \pm $1.8 \%$ ). The percentage of asialo GM1-positive cells showed 

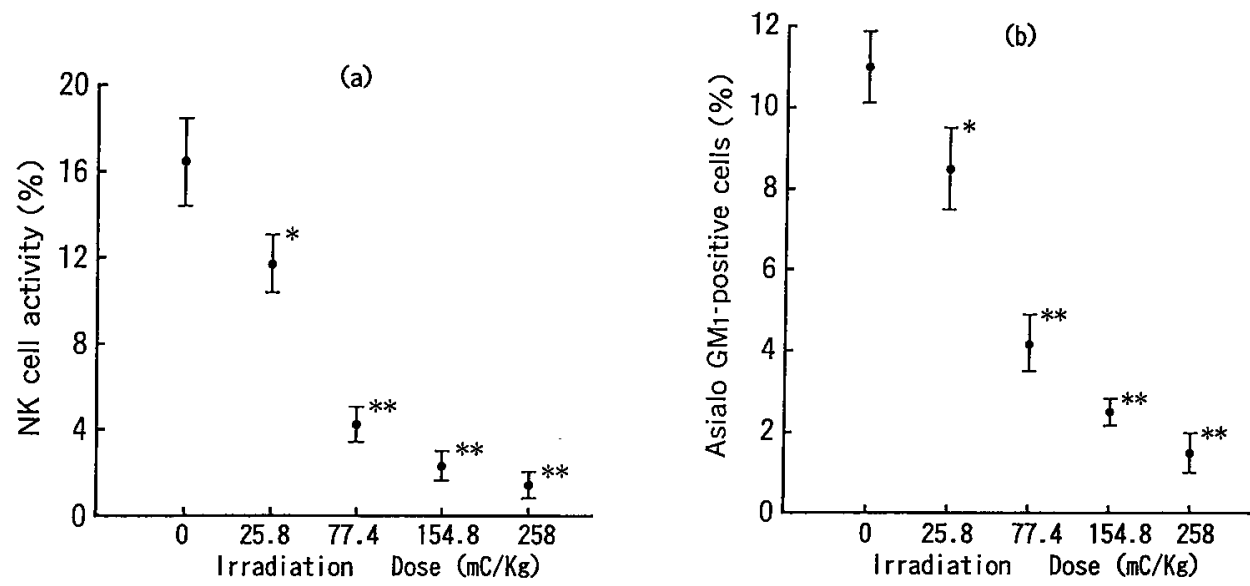

Fig. 1. Effect of soft X-ray irradiation on the NK cell activity (a) and the percentage of asialo GM1positive cells (b) in spleen of mice. Each value and vertical bar show the mean \pm S.E. Significant difference from control: ${ }^{*} \mathrm{p}<0.05, * * \mathrm{p}<0.01$

a significant reduction with $25.8 \mathrm{mC} / \mathrm{kg}$ irradiation $(8.5 \pm$ $0.9 \%$, mean \pm S.E., $\mathrm{p}<0.05), 77.4 \mathrm{mC} / \mathrm{kg}$ irradiation $(4.2 \pm$ $0.7 \%, \mathrm{p}<0.01), 154.8 \mathrm{mC} / \mathrm{kg}$ irradiation $(2.6 \pm 0.3 \%$, $\mathrm{p}<0.01), 258 \mathrm{mC} / \mathrm{kg}$ irradiation $(1.5 \pm 0.5 \%)$ when compared with the non-irradiated control group $(11.1 \pm 0.9 \%)$. The suppression of NK cell activity and the reduction of asialo GM1-positive cells depended on the irradiation doses (Fig. 1).

Natural killer (NK) cells are large granular lymphocytes capable of destroying target cells without prior sensitization [2]. The major role of NK cell is to provide surveillance against cancer and viral infections, since the NK cell activity is evident against neoplastic and virus infected targets [3]. Asialo GM1-positive cells are known to represent NK cells [4]. There are, however few reports on the effects of soft $\mathrm{X}$-ray irradiation, generated for non-destructive radiological examination, on NK cell activity and the percentage of asialo GM1-positive cells in mice.

In our present study, the NK cell activity decreased $73 \%$ and the percentage of NK cells (asialo GM1-positive cells) decreased $74 \%$ after irradiation with $77.4 \mathrm{mC} / \mathrm{kg}$ of soft $\mathrm{X}$ rays. The reduction in the $\mathrm{NK}$ cell activity and asialo GM1-positive cells depended on the irradiation doses. Nesumi et al. [8] reported that the NK cell activity of peripheral blood decreased about $80 \%$ after irradiation with 4 Gy of hard X-rays, and a dose dependent decrease in NK cell activity was observed after irradiation with doses ranging from 4 to $30 \mathrm{~Gy}$. It has also been reported that the percentage of NK cells decreased and NK cells were radiosensitive [10]. These results suggested that soft X-ray irradiation might suppress the NK cell activity of mice to almost the same extent as irradiation with a similar dose of hard X-rays. In this study, we have demonstrated that the NK cell activity and the population of asialo GM1-positive cells were affected by soft X-ray irradiation in graded doses of more than $25.8 \mathrm{mC} / \mathrm{kg}$. Our results also show that a soft $\mathrm{X}$-ray generator for non-destructive examination could be applied to radioimmunological studies in stead of hard Xray.

ACKNOWLEDGMENTS. The authors wish to thank Dr. O. Matuoka for his valuable suggestions and SOFRON Co., Ltd. for the determinations of irradiation dose of soft X-ray.

\section{REFERENCES}

1. Herberman, R. B., Nunn, M. E., and Lavrin, D. H. 1975. Int. J. Cancer 16: 216-229.

2. Herberman, R. B. 1981. Clin. Immunol. Rev. 1: 1-65.

3. Herberman, R. B., Djeu, J. K., Kay, H. D., Ortaldo, J. R., Ricardi, C., and Bonnard, G. D. 1979. Immunol. Rev. 44: 4370.

4. Kasai, T., Yoneda, T., Habu, S., Maruyama, Y., Okumura, K., and Tokunaga, T. 1981. Nature (Lond.) 291: 334-338.

5. Koga, T., Ota, T., Aoki, Y., Sugasawa, M., and Kobayashi, F. 1981. Pharumacometrics 22: 765-776.

6. Makidono, R., Nomoto, K., and Takeya, K. 1978. J. Radiat. Res. 19: 115-125.

7. Makinodan, T., Friedberg, B. H., Tolbert, M. G., and Gengozian, N. 1959. J. Immunol. 83: 184-188.

8. Nesumi, N., Konishi, J., Misaki, T., Ono, K., Abe, M., and Torizuka, K. 1985. Nippon Acta Radiologica 45:752-763.

9. Nunn, M. E. and Herberman, R. B. 1979. J. Natl. Cancer Inst. 62: 765-771.

10. Stewart, C. C., Stevenson, A. P., and Habbersett, R. C. 1988. Int. J. Radiat. Biol. 53: 77-83.

11. Takeuchi, M., Sakurai, H., Suzuki, I., Kushida, H., and Shibata, H. 1981. Jpn.J. Vet. Sci. 43: 449-452.

12. Takeuchi, M., Sakurai, H., Kimoto, M., Suzuki, I., and Shibata, H. 1982. Jpn. J. Vet. Sci. 44: 827-830.

13. Takeuchi, M., Suzuki, I., Shibata, H., and Sato, A. 1984. Jpn. J. Vet. Sci. 46: 733-736.

14. Takeuchi, M., Shibata, H., and Nasu, T. 1992. J. Vet. Med. Sci. 54: 653-658.

15. Visakorpi, R. 1972. Microbiol. Scand. 80: 788-794. 